\title{
Extensive genetic diversity among clinical isolates of Streptococcus pyogenes serotype M5
}

\author{
Meeta Desai,, ${ }^{1}$ Asha Tanna, ${ }^{2}$ Androulla Efstratiou, ${ }^{2}$ Robert George, ${ }^{2}$ \\ Jonathan Clewley ${ }^{1}$ and John Stanley ${ }^{1}$
}

Author for correspondence: John Stanley. Tel: +441812004400. Fax: +441812001569.

Molecular Biology Unit, Virus Reference Division, 1 and Streptococcus and Diphtheria Reference Unit Respiratory and Systemic Infection Laboratory, ${ }^{2}$ Central Public Health Laboratory, 61 Colindale Avenue, London NW9 5HT, UK

\begin{abstract}
The genetic diversity of clinical isolates of Streptococcus pyogenes serotype M5 has been characterized. Strain genotypes were defined by macrorestriction profile, 165 ribotype, emm gene subtype, insertion element IS1239 profile, and exotoxin gene determinant. By these criteria, clinical isolates of M5 constituted a multiplicity of strain clusters rather than a homogeneous population as found for certain serotypes. Distance matrices and an unrooted tree were constructed from macrorestriction data with three rarely cutting endonucleases, determined by PFGE. A single IS 1239 profile was common to $85 \%$ of isolates but there was great diversity of both ribotype and macrorestriction profile, and 18 different emm gene subtypes were detected by PCR-RFLP. DNA sequence analysis of the antigen-coding 5' (hypervariable) region of emm gene amplicons (about $240 \mathrm{bp}$ ) showed that 14/18 exhibited up to $6 \%$ divergence. Four amplicons had highly divergent sequences corresponding to those previously determined for emm 6, emm 11, emm 18 and emm 77. Further serological and hybridization studies were used to analyse the discrepancy between the Lancefield serotype of these strains (M5) and their emm genotype. Overall, this study shows a high degree of genetic diversity in serotype M5, with implications for the Lancefield scheme itself, for the epidemiology of group A streptococci, and for recombinant DNA strategies for $M$ protein-based vaccine development.
\end{abstract}

Keywords: group A Streptococcus, emm gene, polymorphism

\section{INTRODUCTION}

Streptococcus pyogenes group A streptococci (GAS) are causative agents of human diseases which range in severity from pharyngitis to toxic-shock-like syndrome and necrotizing fasciitis. $S$. pyogenes possesses a number of virulence factors, of which the best known is the $M$ protein. The C-terminus of this fibrillar protein is anchored to the bacterial cell membrane, while the $\mathrm{N}$ terminus protrudes outwards from the cell. The $M$ protein confers ability to resist phagocytosis by polymorphonuclear leucocytes in the absence of type-specific antibodies (Fischetti, 1989). Anti-M protein immunity is type-specific (Lancefield, 1962), and more than 80 serotypes can be recognized by precipitin reactions constituting the $M$ serotyping scheme. Type-specific antisera are thought to be directed primarily against the short hypervariable region which follows the conserved leader sequence at the $\mathrm{N}$-terminus of $\mathrm{M}$ protein.

The emm gene encoding $M$ protein can be amplified by PCR with conserved primers (Podbielski et al., 1991; Whatmore et al., 1994), and many emm gene sequences have been established (Beall et al., 1996, 1997; Upton et al., 1996; Whatmore et al., 1994). The sequences of the $5^{\prime}$ regions of emm genes from $79 \mathrm{M}$ serotypes exhibited a phylogeny which was not congruent with that derived for the whole genome by multilocus enzyme electrophoresis (MLEE). This suggests that variation in $\mathrm{emm}$ gene sequences has been generated by horizontal gene transfer and recombination (Whatmore et al., 1994). Similarly, the sequence of the downstream gene, enn, from one strain of serotype M5 has a mosaic structure, consisting of segments of divergent origin (Whatmore \& Kehoe, 1994).

The Lancefield scheme (Lancefield, 1962) for serotyping GAS isolates is based on the association of the $T$ 
agglutinins, the opacity factor $(\mathrm{OF})$ reaction and certain groupings of $M$ serotypes. For example, isolates which are $\mathrm{T} 1, \mathrm{OF}^{-}$are invariably serotype $\mathrm{M} 1$. The $\mathrm{emm}$ gene sequences of most GAS isolates are in agreement with these classical $\mathrm{M}$ and $\mathrm{T}$ antigen associations, but there is recent evidence that a minority of isolates are $\mathrm{T}$ nontypable or contain $\mathrm{emm}$ genes encoding $M$ proteins which have no recorded $\mathrm{T}$-antigen association (Beall et al., 1997).

There is evidence (Cleary et al., 1992; Musser et al., 1991,1993 ) that in the case of serotype M1, a globally distributed (genotypic) clone is responsible for most GAS diseases. By contrast, examination of small sample sets by PFGE and ribotyping alone indicated that other serotypes might be greatly more diverse genetically than is M1 (Stanley et al., 1995).

In this study, we examined the genetic diversity of randomly chosen clinical isolates of serotype M5, a major serotype associated with a wide spectrum of GAS diseases from pharyngitis to severe invasive infections. We analysed strain phylogenies by carrying out genome macrorestriction with three (rather than one) rarely cutting endonucleases, by ribotyping with three endonucleases, and by restriction fragment length polymorphism (RFLP) in and around loci of the transposable insertion element IS1239 (Kapur et al., 1994). We placed other genetic markers (emm gene polymorphism and exotoxin determinants) onto the phylogenetic tree based on macrorestriction. Polymorphism of the $\mathrm{emm}$ gene was investigated by nucleotide sequencing of the $5^{\prime}$ end of the gene and, where indicated, by further serological studies.

\section{METHODS}

Bacterial strains and growth conditions. The type strain (NCTC 8193; obtained from the National Collection of Type Cultures, Colindale, UK), a reference strain traditionally used for producing antisera to $M$ type 5 (strain 100065), and 38 clinical isolates of $S$. pyogenes serotype M5 (Table 1) were analysed. Isolates from the following noninvasive diseases were included: scarlet fever, sore throat, infected skin, vaginitis, and ear and eye infection. Isolates from the following invasive diseases were included: septicaemia, cellulitis, pneumonia, bacteraemia, brain abscess, bursitis, lymphadenitis, chest infection, and renal disease. Streptococci were cultured aerobically at $37^{\circ} \mathrm{C}$ for $18-24 \mathrm{~h}$ on horse blood agar plates, and preserved for reference in blood glycerol $(16 \% \mathrm{v} / \mathrm{v})$ broth (Oxoid) at $-70^{\circ} \mathrm{C}$.

Serological analysis. Isolates were serotyped before and after genotype analysis according to standard methods (Johnson et al., 1996; Lancefield, 1962). Lancefield acid extracts were reexamined for precipitin lines of identity with type-specific antisera against the $M$ type predicted from the relevant $\mathrm{emm}$ amplicon sequence. Standard Ouchterlony double-diffusion tests (Johnson et al., 1996), were used in a format designed to reveal one or more serotype identities.

emm gene polymorphism, $5^{\prime}$ sequence analysis and hybridization studies. The 'all M' PCR primers and conditions of Podbielski et al. (1991) were used for amplification of the $\mathrm{emm}$ gene, and RFLP analysis of emm amplicons was carried out as previously described (Stanley et al., 1996).
Amplicons were purified with Gene Clean (Bio101), and subjected to cycle sequencing using the 'all $M$ ' forward primer of Podbielski et al. (1991) or forward primer 1 of Whatmore \& Kehoe (1994), with the PRISM Dye Terminator Cycle Sequencing kit. Analysis was performed on an ABI 373A DNA sequencer. For four amplicons which had highly divergent sequences from that of emm5 (>6\%; termed $\left.\mathrm{emm}^{*}\right)$, the second strand was also sequenced, using primers designed from the first-strand sequence data (see below).

emm gene hybridization studies were carried out for the four M5 strains (R2223, R2357, R2160 and R2247) from which $\mathrm{emm}^{*}$ products were amplified as follows. Genomic DNA $(5 \mu \mathrm{g})$ of these strains and the M5 type strain was blotted onto Hybond-N (Amersham) membrane (five replicate filters) using a slot-blot apparatus (Stratagene), and fixed by UV crosslinking (Stratagene). The $5^{\prime}$ regions of the four $\mathrm{emm}^{*}$ genes and that of the M5 type strain were amplified using forward primer 1 (Whatmore \& Kehoe, 1994) and five new reverse primers designed from first-strand sequence data (see Results). PCR reactions were carried out under standard conditions, with 25 cycles of denaturation at $94^{\circ} \mathrm{C}$ for $1 \mathrm{~min}$, annealing at $45^{\circ} \mathrm{C}$ for $1 \mathrm{~min}$, and extension at $72^{\circ} \mathrm{C}$ for $1 \mathrm{~min}$ in a Robocycler (Stratagene). Amplicons, ranging in size from 250 to $300 \mathrm{bp}$, were labelled with $\left[\alpha^{32} \mathrm{P}\right] \mathrm{dCTP}$ by random priming (Feinberg \& Vogelstein, 1983) using the Multiprime DNA labelling system (Amersham), and hybridized with individual filters.

Genomic DNA $(5 \mu \mathrm{g})$ of the type strain and the four strains alone was digested with HindIII, electrophoresed in $1.0 \%$ agarose $(55 \mathrm{~V}, 17 \mathrm{~h}$ ), and Southern blotted (five replicate filters). The same $5^{\prime} \mathrm{emm}$ PCR amplicons were labelled with biotin-16-dUTP (random-primed labelling kit; Boehringer Mannheim) and hybridized with these filters. After stringent washing (two washes, $30 \mathrm{~min}$ each, $63{ }^{\circ} \mathrm{C}, 0.16 \times \mathrm{SSC} / 0.1 \%$ SDS), they were developed as previously described (Stanley et al., 1996).

Macrorestriction, PFGE and data analysis. PFGE was carried out following SmaI macrorestriction as previously described (Stanley et al., 1996). For Sfil and NgoAIV macrorestriction, different ramping and electrophoresis conditions were used, as follows: $10-90 \mathrm{~s}$ at $5.5 \mathrm{~V} \mathrm{~cm}^{-1}, 24 \mathrm{~h}, 1.3 \%$ agarose for SfiI; $0.1-30 \mathrm{~s}$ at $5.7 \mathrm{~V} \mathrm{~cm}^{-1}, 23 \mathrm{~h}, 1.1 \%$ agarose for NgoAIV. Genetic relationship between isolates was estimated by using the equation of Nei $\& \mathrm{Li}(1979)$ to calculate $D$ values (distance matrices) for all three enzymes. Estimates of overall restriction site similarity were then used to construct an unrooted tree by the FITCH option of the PHYLIP computer package (Felsenstein, 1988).

Minipreparation of genomic DNA, 165 ribotyping, and exotoxin gene carriage. Genomic DNA was extracted from streptococcal plate cultures as previously described (Stanley $e t$ al., 1995). DNA was digested with XhoI, EcoRI or SacI, electrophoresed, blotted, and hybridized with a $1500 \mathrm{bp} S$. pyogenes 16S rRNA gene probe as previously described (Stanley et al., 1995). Membrane filters were developed colorimetrically, and scanned directly with a ScanMaker IIG (Microtek Lab) into a Power Macintosh 6100/60 (Apple Computer). PCR primers and conditions used for detection of exotoxin genes were as previously described (Stanley et al., 1996).

IS1239 profiling. An 865 bp fragment of IS1239 was amplified by PCR from genomic DNA. The final reaction mixture $(50 \mu \mathrm{l})$ contained $5 \mu \mathrm{l}$ standard PCR buffer (Life Technologies), $3.0 \mathrm{mM}$ magnesium chloride, $200 \mu \mathrm{mol}$ (each) deoxynucleotide triphosphates, $0.6 \mu \mathrm{M}$ of each primer and 2.5 units of Taq 
Table 1. Streptococcus pyogenes M5 isolates and their genotypes

\begin{tabular}{|c|c|c|c|c|c|c|c|}
\hline Isolate & $\begin{array}{c}\text { Year/source (all UK) } \\
\text { of isolation }\end{array}$ & Disease & $\begin{array}{c}\text { emm gene } \\
\text { PCR-RFLP* }\end{array}$ & $\begin{array}{c}\text { Combined } \\
\text { PFGE profile } †\end{array}$ & $\begin{array}{c}\text { Combined } \\
16 S \\
\text { ribotype } \neq\end{array}$ & $\begin{array}{c}\text { spe } \\
\text { genes } \$\end{array}$ & $\begin{array}{c}\text { IS1239 } \\
\text { profile } \|\end{array}$ \\
\hline R0443 & 1991/Surrey & Scarlet fever & $5 . \mathrm{H} 2$ & \#5.1 & $\mathrm{R}-4$ & $\mathrm{ABC}$ & IP3 \\
\hline R0060 & 1995/Sussex & Pneumonia & $5 . \mathrm{H} 2$ & \#5.1 & $\mathrm{R}-4$ & $\mathrm{ABC}$ & IP3 \\
\hline R0065 & 1995/London & Cellulitis & $5 . \mathrm{H} 2$ & $\# 5.1$ & $\mathrm{R}-4$ & $\mathrm{ABC}$ & IP3 \\
\hline R0439 & 1991/Surrey & Scarlet fever & $5 . \mathrm{H} 2$ & $\# 5.1$ & $\mathrm{R}-4$ & $\mathrm{ABC}$ & IP3 \\
\hline $\mathrm{R} 2275$ & 1994/London & Brain abscess & $5 . \mathrm{H} 2$ & $\# 5.1$ & $\mathrm{R}-4$ & $\mathrm{ABC}$ & IP3 \\
\hline R1508 & 1991/Edinburgh & Rheumatic fever & 5.H11 & $\# 5.1$ & $\mathrm{R}-4$ & $\mathrm{ABC}$ & IP3 \\
\hline R0116 & 1995/London & Scarlet fever & $5 . \mathrm{H} 3$ & \#5.1 & $\mathrm{R}-4$ & $\mathrm{ABC}$ & IP3 \\
\hline R1349 & 1995/Salisbury & Bursitis & 5.H8 & $\# 5.1$ & $\mathrm{R}-4$ & $\mathrm{ABC}$ & IP3 \\
\hline $\mathrm{R} 1628$ & 1995/Isle of Wight & Persistent discharge & 5.H8 & $\# 5.1$ & $\mathrm{R}-4$ & $\mathrm{ABC}$ & IP3 \\
\hline $\mathrm{R} 2454$ & 1994/Llanelli & Conjunctivitis & 5.H8 & $\# 5.2$ & $\mathrm{R}-4$ & $\mathrm{ABC}$ & IP3 \\
\hline $\mathrm{R} 2577$ & 1994/Hampton & Septicaemia & $5 . \mathrm{H} 5$ & $\# 5.2$ & $\mathrm{R}-4$ & $\mathrm{ABC}$ & IP3 \\
\hline$R 2606$ & 1995/Worcester & Unknown & $5 . \mathrm{H} 7$ & $\# 5.3 \mathrm{a}$ & $\mathrm{R}-5$ & $\mathrm{BC}$ & IP3 \\
\hline R0126 & 1995/Blackburn & Fatal septicaemia & $5 . \mathrm{H} 7$ & $\# 5.3$ & $\mathrm{R}-5$ & $\mathrm{ABC}$ & IP3 \\
\hline R0304 & 1995/Tyneside & Septicaemia & $5 . \mathrm{H} 2$ & \#5.3 & R-5 & $\mathrm{BC}$ & IP3 \\
\hline R0428 & 1995/Truro & Postnatal pyrexia & $5 . \mathrm{H} 14$ & $\# 5.3$ & $\mathrm{R}-5$ & $\mathrm{AB}$ & IP3 \\
\hline $\mathrm{R} 2356$ & 1994/Carmarthen & Cellulitis & $5 . \mathrm{H} 3$ & $\# 5.4$ & R-5 & $\mathrm{ABC}$ & IP3 \\
\hline $\mathrm{R} 2644$ & 1994/Llanelli & Pyrexia & $5 . \mathrm{H} 3$ & $\# 5.4$ & R-5 & $\mathrm{ABC}$ & IP3 \\
\hline R1635 & 1995/Carlisle & Septicaemia & $5 . \mathrm{H} 3$ & \#5.5 & $\mathrm{R}-4$ & $\mathrm{ABC}$ & IP3 \\
\hline R0379 & 1995/Barnsley & Sore throat & $5 . \mathrm{H} 3$ & $\# 5.5$ & $\mathrm{R}-4$ & $\mathrm{ABC}$ & IP3 \\
\hline R0161 & 1995/Sheffield & Lymphadenitis & $5 . \mathrm{H} 6$ & $\# 5.5$ & $\mathrm{R}-4$ & $\mathrm{ABC}$ & IP3 \\
\hline $\mathrm{R} 2785$ & 1994/Epsom & None & $5 . \mathrm{H} 9$ & \#5.5 & $\mathrm{R}-8$ & $\mathrm{ABC}$ & IP3 \\
\hline $\mathrm{R} 1388$ & 1995/Exeter & Ear infection & $5 . \mathrm{H} 3$ & $\# 5.6$ & $\mathrm{R}-4$ & $\mathrm{ABC}$ & IP3 \\
\hline R1648 & 1970/Unknown & Unknown & 5.H12 & \#5.7 & R-9 & $\mathrm{AB}$ & IP3 \\
\hline R0022 & 1995/Nottingham & Unknown & $5 . \mathrm{H} 2$ & $\# 5.8$ & $\mathrm{R}-4$ & $\mathrm{ABC}$ & IP3 \\
\hline R0536 & 1991/London & Pharyngitis & $5 . \mathrm{H} 2$ & $\# 5.8$ & $\mathrm{R}-4$ & $\mathrm{ABC}$ & IP3 \\
\hline R2919 & 1991/Exeter & Jaundice & $5 . \mathrm{H} 10$ & $\# 5.8$ & $\mathrm{R}-4$ & $\mathrm{ABC}$ & IP3 \\
\hline R0009 & 1995/Llanelli & Vaginitis & $5 . \mathrm{H} 3$ & $\# 5.8$ & $\mathrm{R}-4$ & $\mathrm{ABC}$ & IP3 \\
\hline R1973 & 1991/Luton & Septicaemia & $5 . \mathrm{H} 3$ & $\# 5.8$ & $\mathrm{R}-4$ & $\mathrm{ABC}$ & IP3 \\
\hline R0701 & 1991/Luton & Septicaemia & $5 . \mathrm{H} 3$ & $\# 5.8$ & $\mathrm{R}-4$ & $\mathrm{ABC}$ & IP3 \\
\hline$R 2264$ & 1994/Isle of Wight & Post partum & $5 . \mathrm{H} 4$ & $\# 5.8$ & $\mathrm{R}-4$ & $\mathrm{ABC}$ & IP3 \\
\hline R0574 & 1994/Stroud & Unknown & $5 . \mathrm{H} 18$ & $\# 5.9$ & $\mathrm{R}-10$ & B & IP5 \\
\hline $\mathrm{R} 2357$ & 1994/London & Chest infection & $5 . \mathrm{H} 18$ & $\# 5.10$ & $\mathrm{R}-7$ & $\mathrm{BC}$ & - \\
\hline R2160 & 1994/London & Vaginitis & $5 . \mathrm{H} 15(\mathrm{NC})$ & $\# 5.11$ & $\mathrm{R}-6$ & $\mathrm{BC}$ & IP4 \\
\hline R2223 & 1994/Stoke-on-Trent & Pneumonia & 5.H16 (NC) & $\# 5.12$ & $\mathrm{R}-3$ & $\mathrm{BC}$ & IP2 \\
\hline R2247 & 1994/Dorchester & Bacteraemia & $5 . \mathrm{H} 17$ & $\# 5.13$ & $\mathrm{R}-2$ & B & - \\
\hline R0581 & 1995/Romford & Wound infection & $5 . \mathrm{H} 13$ & $\# 5.14$ & $\mathrm{R}-5$ & $\mathrm{BC}$ & IP3 \\
\hline $\mathrm{R} 2550$ & 1994/Grimsby & Renal disease & $5 . \mathrm{H} 3$ & $\# 5.14$ & $\mathrm{R}-5$ & $\mathrm{BC}$ & IP3 \\
\hline R0307 & 1995/Bristol & Septicaemia & $5 . \mathrm{H} 2$ & $\# 5.14$ & $\mathrm{R}-5$ & $\mathrm{BC}$ & IP3 \\
\hline 100065 & 1959/UK & Unknown & 5.H1 & $\# 5.15$ & $\mathrm{R}-1$ & $\mathrm{BC}$ & IP1 \\
\hline NCTC 8193 & 1950/London & Puerperal fever & 5.H1 & $\# 5.15$ & $\mathrm{R}-1$ & $\mathrm{AB}$ & IP1 \\
\hline
\end{tabular}

* emm gene PCR amplification followed by RFLP analysis with HaeIII; NC, not cut by HaeIII.

† Numbers following the combined PFGE profile, \#, indicate a unique RFLP obtained by combining three endonuclease digestions (SmaI, Sfil, NgoAIV).

$\ddagger$ Numbers following the combined ribotype (with $E c o$ RI and $S a c I$ ), R, indicate different patterns of hybridization with the probe.

$\$$ Streptococcal pyrogenic exotoxin genes $A, B, C$ determined by PCR.

$\|$ Numbers following the insertion sequence IS1239 profile, IP, indicate different $P v u I$ patterns of hybridization with the probe; -, absence of the element.

polymerase. Samples overlaid with $100 \mu \mathrm{l}$ of mineral oil were subjected to 25 cycles of denaturation at $94^{\circ} \mathrm{C}$ for $1 \mathrm{~min}$, annealing at $51^{\circ} \mathrm{C}$ for $1 \mathrm{~min}$, and extension at $72^{\circ} \mathrm{C}$ for $1 \mathrm{~min}$ in a Robocycler (Stratagene). PCR products were labelled with
biotin-16-dUTP using a random-primed labelling kit (Boehringer Mannheim). Ten micrograms of genomic DNA was digested with PvuII, electrophoresed in $0.7 \%$ agarose $(55 \mathrm{~V}$, $16 \mathrm{~h}$ ), Southern blotted and hybridized. Stringent filter wash- 
$\begin{array}{lllllllllllllllllll}1 & 2 & 3 & 4 & 5 & 6 & 7 & 8 & 9 & 10 & 11 & 12 & 13 & 14 & 15 & 16 & 17 & 18 & 19\end{array}$

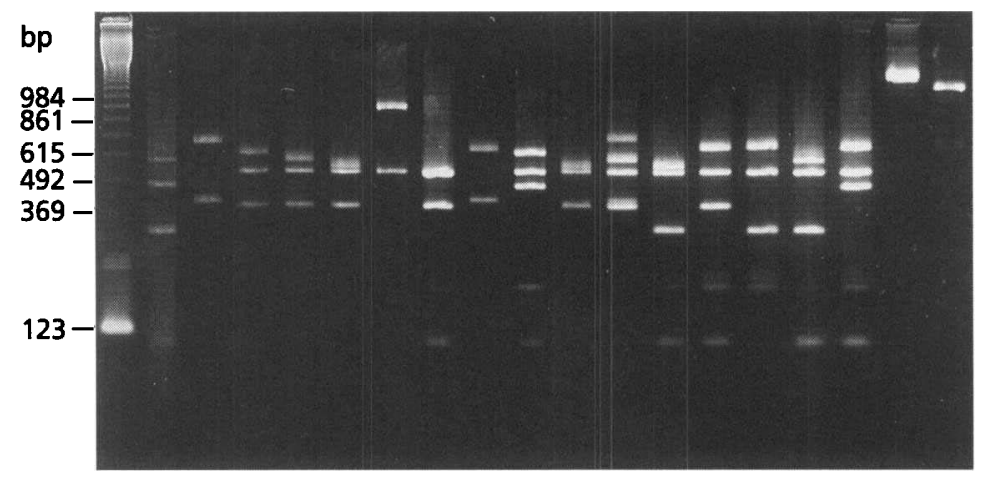

Fig. 1. PCR-RFLP subtypes (Haelli) of emm gene amplicons. Lane 1, 123 bp ladder (size markers); lane 2, $\mathrm{H} 1$; lane 3, H17; lanes 4-8, $\mathrm{H} 2-\mathrm{H} 6$; lane 9, H18; lanes 10-17, $\mathrm{H} 7-\mathrm{H} 14$; lanes 18 and 19, H15 and $\mathrm{H} 16$ (amplicons not digested by HaellI).

ing conditions (two washes, $30 \mathrm{~min}$ each, $64^{\circ} \mathrm{C}, 0 \cdot 16 \times$ SSC $/ 0 \cdot 1 \%$ SDS) were employed, and detection of hybridized probe was as previously described (Stanley et al., 1995).

\section{RESULTS}

\section{emm gene polymorphism and sequence analysis}

emm gene PCR amplicons from all M5 isolates varied in size from approximately 1050 to $2100 \mathrm{bp}$. Analysis for HaellI polymorphisms detected 18 RFLPs. Two amplicons (H17 and H18) were not digested (Fig. 1, lanes 18 and 19). Of the 40 isolates, $23 \%$ and $25 \%$, respectively, belonged to two RFLP groups, $\mathrm{H} 2$ and $\mathrm{H} 3$ (Fig. 1, lanes 4 and 5). The 16 remaining RFLP groups consisted of one to three strains each (Table 1; Fig. 1).

We sequenced 240 bases from the $5^{\prime}$ region of the 18 amplicons (Fig. 1). These sequences were aligned using MegAlign module of Lasergene (DNASTAR). Fourteen of them (Fig. 2a) exhibited $>94 \%$ identity to that of the serotype M5 type strain, NCTC 8193, whose sequence was termed emm5.H1, and which was identical to that previously published (Whatmore $\&$ Kehoe, 1994). Four amplicons (termed $e m m^{*}$ ) exhibited marked divergence (Fig. 2b). Nonetheless, all amplicons contained the nucleotide sequence 5'-TCGCTTAGAAAATTAA-3', which is complementary to the forward primer designed to distinguish sequences in the $5^{\prime}$ conserved regions of emm genes from corresponding regions of enn or $m r p$ genes (Whatmore et al., 1994; Whatmore \& Kehoe, 1994). Sequences of the four $\mathrm{emm}^{*}$ amplicons were found to be highly similar $(>98 \%)$ to those of $\mathrm{emm}$ genes other than $\mathrm{emm} 5$ (GenBank data). The $\mathrm{emm}^{*}$ amplicons originated from strains R2247 (sequence identity with emm77), R2223 (emm6), R2160 (emm18) and R2357 (emm11).

\section{Further analysis of M5 strains with $\mathrm{emm}^{*}$ sequences}

PCR primers to amplify the $5^{\prime}$ region specific to a particular $\mathrm{em}^{*}$ gene were designed for each strain, and also for the type strain, using first-strand sequence data. The reverse primers were: strain R2223, 5'-ATCTGTTAAGTTTTTATTC-3' ; strain R2357, 5' -ATTTTTTGTCTCTTCATTTT-3'; strain R2160, 5'-AGTTTTT-
AAATCATCATTC-3' ; strain R2247, 5' -TTCTGATTTTTTTTCAAG- $3^{\prime}$, and M5 type strain, 5'-AACTCAGCAGTCTTACGTTC-3'. When used with the forward primer 1 (Whatmore \& Kehoe, 1994), products varying in size from $250 \mathrm{bp}$ to $300 \mathrm{bp}$ were amplified, and used as probes.

The resulting slot-blot and Southern blot hybridization data (Table 2) showed that these $\mathrm{emm}^{*}$-specific amplicons hybridized with their genomic DNA of origin in all cases. The emm5-amplicon hybridized only with itself and conversely, none of the $\mathrm{emm}^{*}$ amplicons hybridized with the type strain. The $\mathrm{emm}^{*}$ amplicons from strains R2223 and R2160 hybridized only with their own genomic DNA. emm* amplicons from strains R2247 and R2357 also cross-hybridized with genomic DNA of each other.

Further serological characterization was carried out for the four strains above, whose emm* sequences corresponded to emm6 (strain R2223), emm11 (strain R2357), $e m m 18$ (strain R2160) and emm77 (strain R2247). As seen in Fig. 3, M5 precipitin lines of identity were seen with Lancefield extracts prepared from these four strains. However, lines of identity were also seen for extracts of these strains with anti-M6 (strain R2223), anti-M11 (strain R2357), anti-M18 (strain R2160) and anti-M77 (strain R2247).

\section{Pyrogenic exotoxin determinants}

A PCR amplicon from the $s p e B$ gene was generated from all isolates. Five per cent of the isolates carried only this exotoxin determinant, whereas $65 \%$ carried speA, B and $C$ genes. Among the remaining isolates, three carried spe $A B$ and nine carried speBC (Table 1).

\section{Macrorestriction (PFGE) profiles}

Macrorestriction was carried out serially with SmaI, Sfi or NgoAIV, whose restriction sites are GC-rich. Of 14 Smal profiles detected, $33 \%$ of isolates shared one, $18 \%$ another, and eight isolates had unique profiles. Of $13 \mathrm{Sfil}$ profiles, none was predominant : three profiles accounted for $28 \%, 18 \%$ and $15 \%$ of isolates, and seven were strain-specific. Of 13 NgoAIV profiles detected, one 
(a)
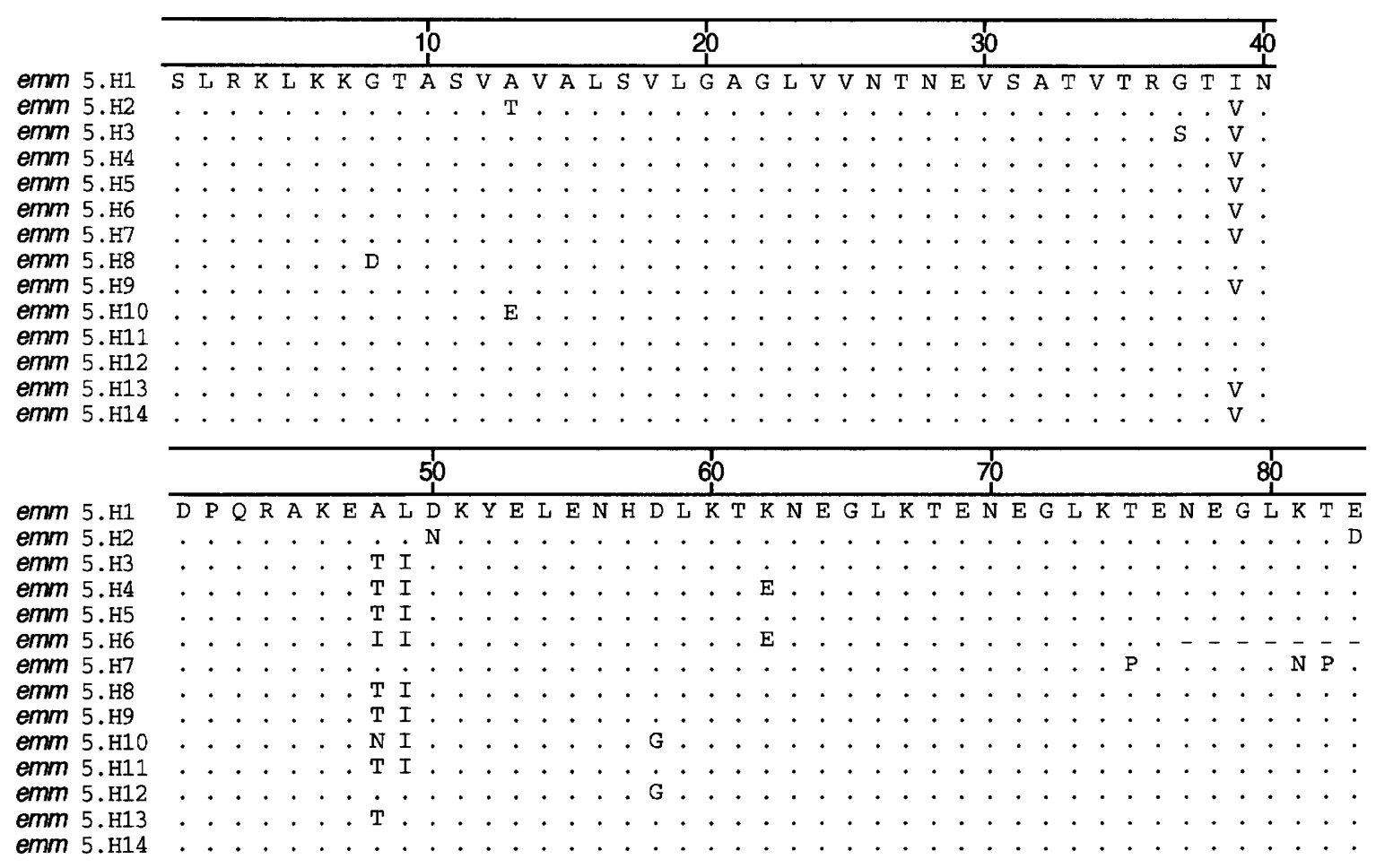

(b)

\begin{tabular}{|c|c|}
\hline $\begin{array}{l}e m m^{*} \cdot H 15 \\
e m m^{\star} \cdot H 16 \\
e m m^{*} \cdot H 17 \\
e m m^{*} \cdot \text { H18 }\end{array}$ & 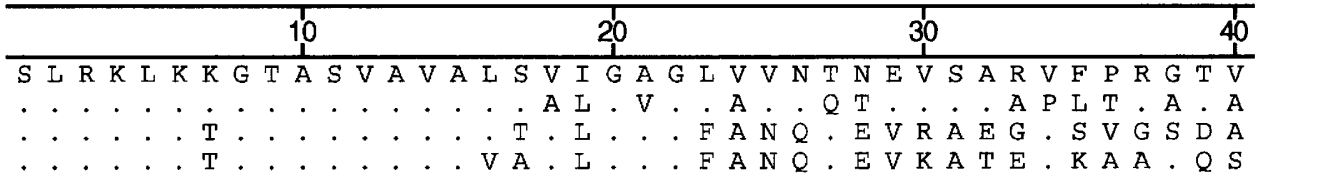 \\
\hline & $60 \quad 70$ \\
\hline $\begin{array}{l}m m^{*} \cdot H 15 \\
m m^{*} \cdot H 16 \\
m m^{*} \cdot H 17 \\
m m^{*} \cdot H 18\end{array}$ & 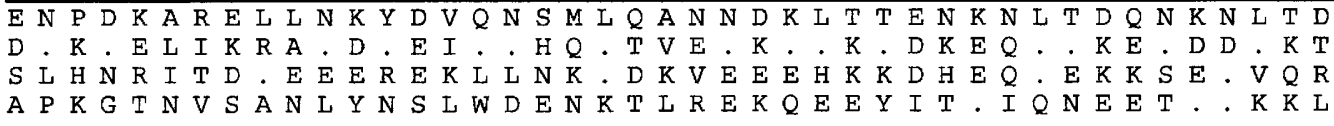 \\
\hline
\end{tabular}

Fig. 2. Deduced amino acid sequences corresponding to the $\mathrm{N}$-terminal regions of emm subtypes (cf. Fig. 1). The dots indicate positions with identity to the first sequence in each panel. (a) Sequences of $13 \mathrm{emm} 5$ subtypes exhibiting $>95 \%$ sequence identity to that of the type strain NCTC 8193 (emm5.H1; GenBank accession number SP02480). In emm5.H6 (GenBank accession number AJ223285), dashes represent probable deletion of a 7-amino-acid (A) repeat. (b) Sequences of four subtypes showing marked divergence, and consequently labelled emm* (GenBank accession numbers AJ223286-AJ223289).

accounted for $53 \%$ of isolates, and seven were strainspecific (data not shown).

Individual profiles obtained with three endonucleases were combined to give 15 'combined profiles' (Table 1). For example, serotype M5 isolates with the $S m a I$ profile 8, Sfil profile 4 and $\mathrm{NgoAIV}$ profile 4 were designated 'combined profile' \#5.1. Similarly, combined profile \#5.2 represents the combination SmaI profile 8, Sfi profile 4, NgoAIV profile 6 and so forth. Each designated 'combined profile' was differentiated by at least three band differences with at least one endonuclease. Less than three band differences with any endonuclease was taken as indicative of clonal relationship (Tenover $\mathrm{et}$ al., 1995 ) and designated by a suffix letter. Thus, \#5.3 was related to \#5.3a by less than three band differences in the SmaI profile.

\section{5 ribotypes}

Genomic DNA was digested with EcoRI, SacI or XhoI. Among the $\mathbf{4 0}$ isolates, polymorphism was extensive with all enzymes. Seven RFLPs were detected in both XhoI digests and EcoRI digests, with 34/40 (85\%) isolates sharing a single ribotype. Of the remaining six isolates, five belonged to four 'atypical' strains. The 
Table 2. Summary of results of slot-blot and Southern blot hybridizations

\begin{tabular}{|lccccc|}
\hline \multirow{2}{e}{$m m$ probet } & \multicolumn{5}{c|}{ Genomic DNA from strain: } \\
\cline { 2 - 6 } & NCTC 8193 & R2247 & R2223 & R2160 & R2357 \\
\hline$e m m 5$ & + & - & - & - & - \\
$e m m^{*}(77)$ & - & + & - & - & + \\
$e m m^{*}(6)$ & - & - & + & - & - \\
$e m m^{*}(18)$ & - & - & - & + & - \\
$e m m^{*}(11)$ & - & + & - & - & + \\
\hline
\end{tabular}

† Approximately $250 \mathrm{bp}$ amplicon representing the $5^{\prime}$ end of the emm gene amplified from the strain shown. The number in parentheses indicates the $\mathrm{emm}$ gene to which the respective $\mathrm{emm}^{*}$ amplicon corresponds.

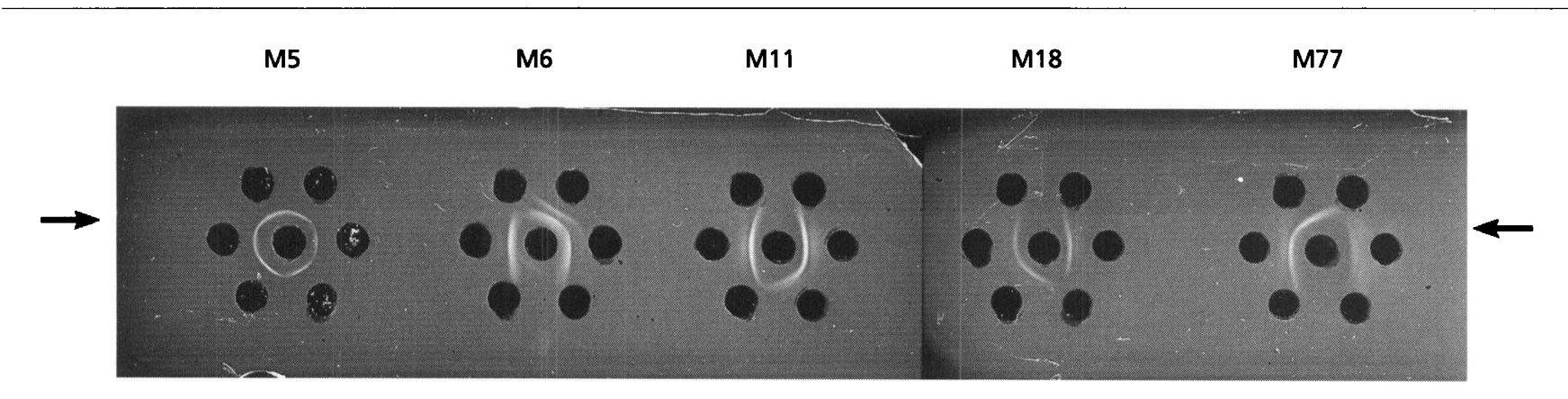

Fig. 3. M-precipitin reactions of strains with $\mathrm{emm}^{*}$ gene amplicons. The central well within each set contains antiserum to serotypes M5, M6, M11, M18 or M77 as indicated above the photograph. The outer wells of each set contained Lancefield acid extracts of test and control strains. Wells 1 and 4 of each set (arrowed) contained homologous control extract for the $M$ type. Wells 2, 3, 5 and 6 (reading clockwise from the arrow on the left) contained acid extracts of strains R2247, R2223, R2160 and R2357. In each case there is reaction with two wells containing the homologous control extracts, and with one other well: M6 with well 3, M11 with well 5, M18 with well 6 and M77 with well 2.

most discriminatory enzyme, SacI, detected ten ribotypes among the isolates. A 'combined ribotype' was derived by sequential addition of data from these enzymes. Ten 'combined ribotypes' were defined; seven of these occurred only in single strains (Table 1).

\section{IS1239 profiling}

PCR primers were designed with Lasergene (DNASTAR) software, from the published sequence of IS1239. The forward primer 5'-ATGCAAGATTATTATACACC-3' and reverse primer $5^{\prime}$-TCTTTAGGGGTCGTTGTTTTGGTA-3' generated an 865 bp product, corresponding to an internal fragment of IS1239. This amplicon was used to probe genomic Southern blots made with PvuII, which has a single restriction site lying $146 \mathrm{bp}$ downstream of the forward PCR primer. The rationale was that each genomic copy of IS1239 should yield two hybridizing PvuII fragments ('IS1239 bands').

Thirty-eight of the 40 M5 isolates carried IS1239. Five IS1239 profiles were found. The number of IS1239 bands varied from 2 to 24 , and their sizes varied from 0.7 to $12.0 \mathrm{kbp}$. The type and reference strains of serotype M5 shared profile IP1 (Fig. 4, lanes 2 and 5), while 33 clinical isolates shared a closely related IS1239 profile, termed IP3 (Fig. 4, lane 1). Of the five remaining isolates (all containing $e m m^{*}$ genes - see above), three had unique profiles (Fig. 4, lanes 4,6 and 7), and two lacked the element (Fig. 4, lane 3).

\section{Analysis of genetic relationships between strains}

Distance matrices for the three PFGE endonucleases were added, and used to construct a 'combined profile' dendrogram (Fig. 5). Ribotype data (Table 1) and IS profiling were concordant with this dendrogram, except for one cluster of strains (bracketed in Fig. 5) - those from which $\mathrm{emm}^{*}$ amplicons were generated. A striking feature of the tree is the very high level of genetic diversity within serotype M5. There were 15 strain clusters within only 40 randomly chosen clinical isolates. Some of these (e.g. R0443 to R1628 and R0022 to R0701, Fig. 5) shared the same ribotype and spe genes, others (e.g. R1026 to R0428) shared the same ribotype but were diverse in spe genes, while yet others were diverse with respect to both ribotype and spe genes (Table 1). Even if two isolates had identical PFGE profiles with all three endonucleases, they often differed at other genetic markers. For example, four emm5 gene subtypes occurred among the otherwise identical strain cluster R0022 to R0701. Some strains within a PFGE cluster had the same emm5 gene subtype, while others within the 


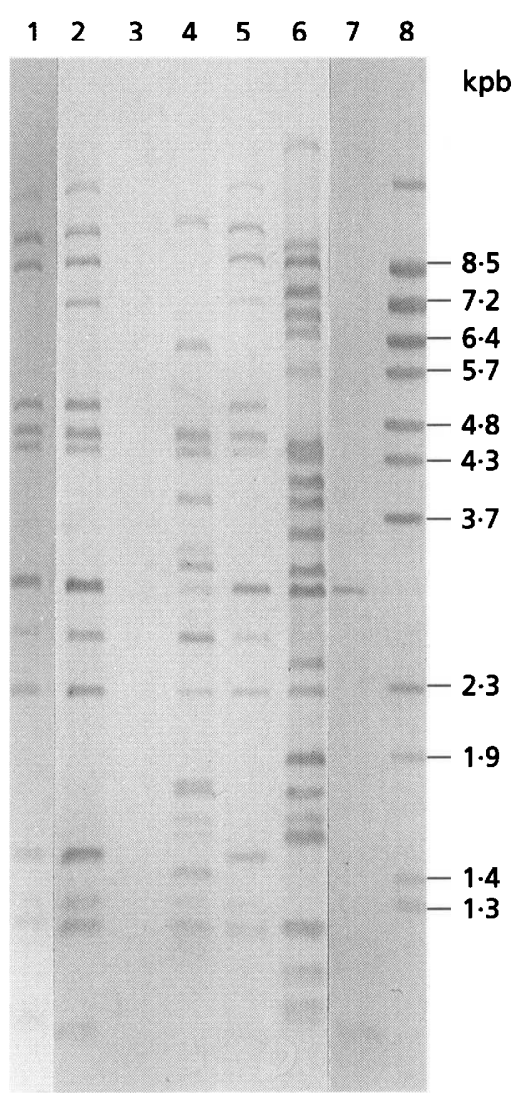

Fig. 4. IS1239 profiles (IP) of serotype M5 strains. Genomic Southern blot made with Pvull and hybridized with 865 bp internal fragment of IS1239. Lane 1, IP3; lanes 2 and 5, IP1; lane 3, isolate lacking the insertion element; lanes 4, 6 and 7, IP2, IP4 and IP5; lane 8, bacteriophage lambda DNA digested with BstEll (size markers).

same PFGE cluster had different emm5 gene subtypes (e.g. R0443 to R1628 and R0022 to R0701, Fig. 5). The type and reference strains, NCTC 8193 and 100065, were genetically dissimilar to contemporary M5 strains (consistent with their related but distinct IS1239 profiles - see above).

The strain cluster bracketed in Fig. 5 was exceptional and is placed in the tree provisionally (dashed lines), only on the basis of macrorestriction. The strains in this cluster, which were diverse with respect to all genetic markers, did not share the IS1239 profile common to other M5 strains: two lacked the element, while three had unique and unrelated IS1239 profiles (Fig. 4, lanes 4, $6,7)$. Their ribotypes were divergent from each other, and from other isolates in the study. Most notably, divergent $\mathrm{emm}^{*}$ amplicons identified by nucleotide sequencing (see above) were generated from them.

\section{DISCUSSION}

Among a relatively small set of serotype M5 isolates, the $\mathrm{emm}$ gene was found to be extensively polymorphic. Sequence analysis confirmed that 14 of the 18 subtypes detected by PCR-RFLP were readily recognizable as alleles of emm5 (Fig. 2a). However, the four emm* subtypes had highly divergent nucleotide sequences (Fig. $2 \mathrm{~b})$, and these corresponded to other known emm genes: emm6, emm11, emm18 and emm 77 .

With respect to molecular epidemiology, emm gene polymorphism alone was extensive enough to differentiate within PFGE profile. PCR-RFLP thus offers a straightforward method of subtyping, and it is shown here to be valid by parallel nucleotide sequence analysis. The genotyping methods reported showed a general hierarchical relationship: this is exemplified by congruence of the IS1239 profile, ribotype and PFGE profile in defining strains and clones within serotype M5 (see Table 1). The speA and speC genes were unlinked to other markers, as expected for bacteriophage-encoded determinants (Yu \& Ferretti, 1991). The type and reference M5 strains had an IS1239 profile (Fig. 4, lanes 2 and 5) which differed by a single IS1239 band from the predominant profile found in contemporary M5 strains (Fig. 4, lane 1). Despite the extensive diversity among other markers, a common ancestry for most M5 strains is indicated by these related IS1239 profiles, IP1 and IP3. The utility of IS1239 in the present study parallels that of other insertion sequences in establishing epidemiological clonality among clinical isolates of Salmonella and Mycobacterium tuberculosis (Stanley \& Saunders, 1996).

Given that these IS1239 profiles may be typical for serotype M5, it is also noteworthy that the four strains carrying $\mathrm{emm}^{*}$ genes exhibited unrelated IS profiles or did not even harbour the element. Furthermore, EcoRI ribotypes for strains R2223 and R2357 matched those previously described for strains of serotypes M6 and M11, corresponding to their emm gene sequences (Stanley et al., 1995) - no such comparative data were available for the other two strains carrying $\mathrm{emm}^{*}$ genes.

These four strains were originally (and repeatedly) serotyped as M5 according to classic serological methods (Johnson et al., 1996). According to the Lancefield scheme, they would not have been tested against individual M antisera for types M6, M11, M18 or M77. This is because the first stage of serotyping comprises the $T$ agglutinin reaction; in this case the four strains are $\mathrm{T} 5 / 27 / 44$. The next stage is the opacity factor (OF) reaction; all four strains are $\mathrm{OF}^{-}$. Isolates are then screened against $M$ antisera defined by the scheme as related - in this case M5 and M12. The scheme does not recognize serotypes $\mathrm{M} 6, \mathrm{M} 11, \mathrm{M} 18$ or $\mathrm{M} 77$ to be related to isolates carrying the T5/27/44 complex antigens (Johnson et al., 1996).

Phenotypically, the Lancefield serological identity of these isolates is M5. However, sequence analysis of both strands of $5^{\prime}$ hypervariable region of their emm amplicons demonstrated identity to $\mathrm{emm}$ genes other than emm5. Hybridization studies indicated that the emm5 gene was not present in these four strains; it is therefore possible that their M5 serodeterminant is not the hypervariable region of their emm gene. In summary, 


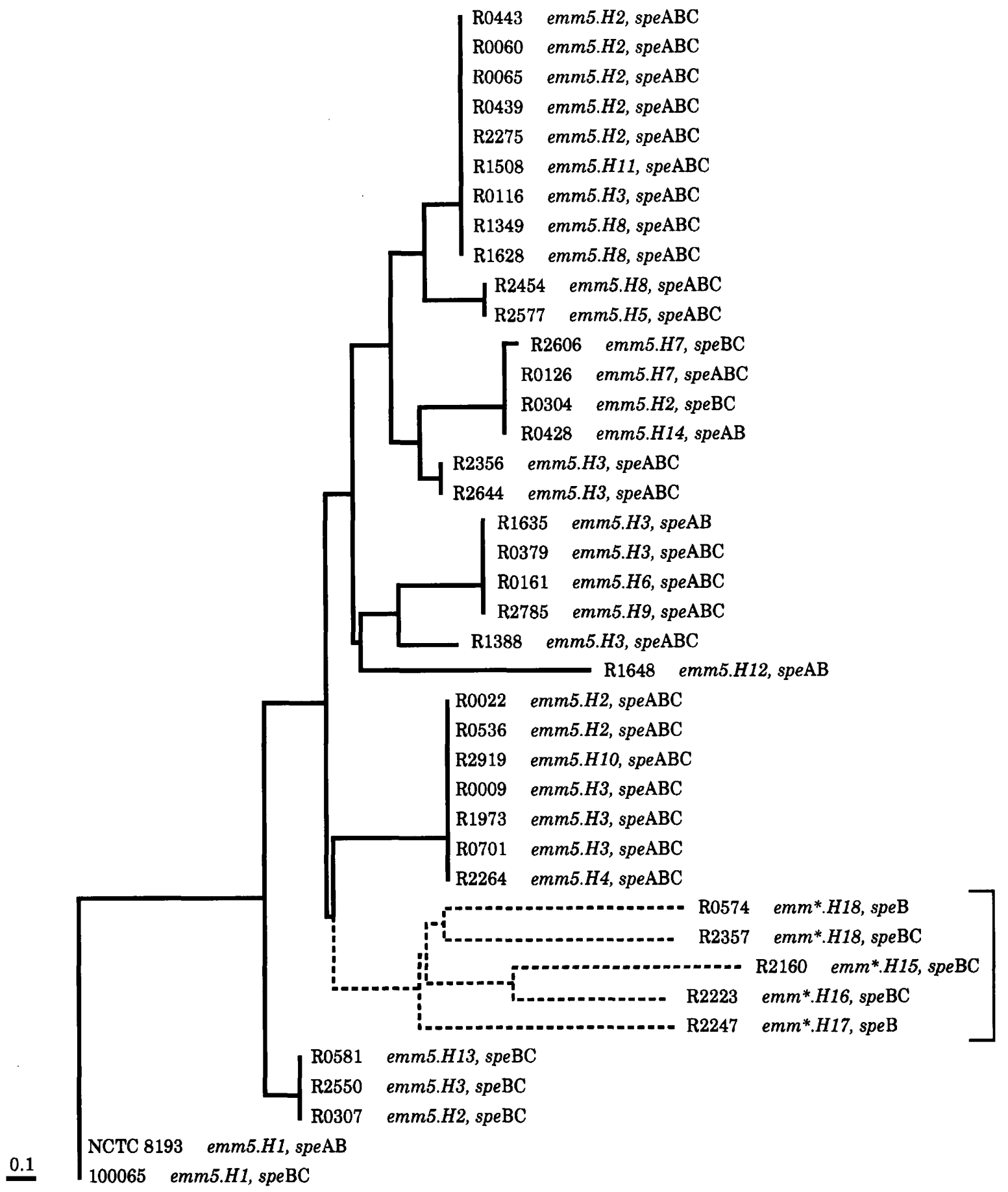

Fig. 5. Dendrogram showing relationships between serotype M5 isolates, inferred (following PFGE) from overall restriction site similarities estimated by the equation of Nei \& Li (1979). These were used to construct an unrooted tree by the FITCH option of the PHYLIP package. Respective emm subtypes and spe determinants are shown next to the strain numbers. The cluster of strains (bracketed, with branching shown by dashed lines) with emm* genes are placed here provisionally - other markers would suggest they are unrelated.

these strains show no collinearity between Lancefield serotype as determined by classical methods and emm gene hypervariable region sequence, or, for that matter, between Lancefield serotype and overall genotype (Fig. 5). Again, M77 and M11 are considered classically to be
$\mathrm{OF}^{+}$serotypes, so that this phenotypic association is also previously unreported. These observations are important since the strains concerned represent over $10 \%$ of M5 isolates in this study. Our results further extend the evidence provided by Beall et al. (1997) that 
classical $M$ and $T$ antigen associations are not always consistent with $\mathrm{emm}$ gene sequence data for a minority of GAS strains.

Data presented in this report will be relevant to the methodology and design of epidemiological studies, and to any debate about the most appropriate way of $M$ typing group A streptococci. Beall et al. (1997) have commented that supplementation of Lancefield serotyping with $\mathrm{emm}$ gene sequencing greatly improves the efficiency and accuracy of epidemiological studies. Results presented in this report support and extend this concept. We have also shown that emm gene PCR-RFLP is a rapid and cost-effective way of identifying $\mathrm{emm}$ sequence type, and such data are congruent with chromosomal genotype as measured by ribotype, IS1239 profile and PFGE profile. It should also be noted that recombinant DNA strategies for $M$ protein vaccine development will need to take into account the extensive $\mathrm{emm}$ gene polymorphism found within important serotypes like M5.

\section{ACKNOWLEDGEMENTS}

We thank Jacqueline Xerry and Mark Broughton for technical assistance with ribotyping and radiolabelling experiments, and Philip Mortimer for critically reading the manuscript.

\section{REFERENCES}

Beall, B., Facklam, R. \& Thompson, T. (1996). Sequencing $\mathrm{emm}$ specific PCR products for routine and accurate typing of group A streptococci. J Clin Microbiol 34, 953-958.

Beall, B., Facklam, R., Hoenes, T. \& Schwartz, B. (1997). Survey of emm gene sequences and $\mathrm{T}$-antigen types from systemic Streptococcus pyogenes infection isolates collected in San Francisco, California; Atlanta, Georgia ; and Connecticut in 1994 and 1995. J Clin Microbiol 35, 1231-1235.

Cleary, P. P., Kaplan, E. L., Handley, J. P., Wlazlo, A., Kim, M. H., Hauser, A. R. \& Schlievert, P. M. (1992). Clonal basis for resurgence of serious Streptococcus pyogenes disease in the 1980s. Lancet 339, 518-521.

Feinberg, A. P. \& Vogelstein, B. (1983). A technique for radiolabelling DNA restriction endonuclease fragments to high specific activity. Anal Biochem 132, 6-13.

Felsenstein, J. (1988). PHYLIP : phylogenetic inference package. Version 3.0. Seattle: University of Washington.

Fischetti, V. A. (1989). Streptococcal M protein: molecular design and biological behavior. Clin Microbiol Rev 2, 285-314.

Johnson, D. R., Kaplan, E. L., Sramek, J., Bicova, R., Havlicek, J., Havlickova, H., Motlova, J. \& Kriz, P. (1996). Laboratory Diagnosis of Group A Streptococcal Infections. Geneva: World Health Organization.

Kapur, V., Reda, K. B., Li, L. L., Ho, L. J., Rich, R. R. \& Musser, J. M. (1994). Characterization and distribution of insertion sequence IS1239 in Streptococcus pyogenes. Gene 150, 135-140.
Lancefield, R. C. (1962). Current knowledge of type-specific M antigens of group A streptococci. J Immunol 89, 307-313.

Musser, J. M., Hauser, A. R., Kim, M. H., Schlievert, P. M., Nelson, K. \& Selander, R. K. (1991). Streptococcus pyogenes causing toxicshock-like syndrome and other invasive diseases: clonal diversity and pyrogenic exotoxin expression. Proc Natl Acad Sci USA 88, $2668-2672$.

Musser, J. M., Kapur, V., Kanjilal, S. \& 11 other authors (1993). Geographic and temporal distribution and molecular characterization of two highly pathogenic clones of Streptococcus pyogenes expressing allelic variants of pyrogenic exotoxin A (Scarlet fever toxin). J Infect Dis 167, 337-346.

Nei, M. \& Li, W. (1979). Mathematical model for studying genetic variation in terms of restriction endonucleases. Proc Natl Acad Sci USA 76, 5269-5273.

Podbielski, A., Melzer, B. \& Lutticken, R. (1991). Application of the polymerase chain reaction to study the $M$ protein (-like) gene family in beta-hemolytic streptococci. Med Microbiol Immunol 180, 213-227.

Stanley, J. \& Saunders, N. (1996). DNA insertion sequences and the molecular epidemiology of Salmonella and Mycobacterium. J Med Microbiol 45, 236-251.

Stanley, J., Linton, D., Desai, M., Efstratiou, A. \& George, R. (1995). Molecular subtyping of prevalent M serotypes of Streptococcus pyogenes causing invasive disease. J Clin Microbiol 33, 2850-2855.

Stanley, J., Desai, M., Xerry, J., Tanna, A., Efstratiou, A. \& George, R. (1996). High-resolution genotyping elucidates the epidemiology of Group A streptococcal outbreaks. J Infect Dis 174, 500-506.

Tenover, F. C., Arbeit, R. D., Goering, R. V., Mickelsen, P. A., Murray, B. E., Persing, D. H. \& Swaminathan, B. (1995). Interpreting chromosomal DNA restriction patterns produced by pulsed-field gel electrophoresis: criteria for bacterial strain typing. J Clin Microbiol 33, 2233-2239.

Upton, M., Carter, P. E., Orange, G. \& Pennington, T. H. (1996). Genetic heterogeneity of $M$ type 3 group A streptococci causing severe infections in Tayside, Scotland. J Clin Microbiol 34, 196-198.

Whatmore, A. M. \& Kehoe, M. A. (1994). Horizontal gene transfer in the evolution of group A streptococcal $\mathrm{emm}$-like genes: gene mosaics and variation in Vir regulons. Mol Microbiol 11, 363-374.

Whatmore, A. M., Kapur, V., Sullivan, D. J., Musser, J. M. \& Kehoe, M. A. (1994). Non-congruent relationships between variation in $\mathrm{emm}$ gene sequences and the population genetic structure of group A streptococci. Mol Microbiol 14, 619-631.

Yu, C. E. \& Ferretti, J. J. (1991). Molecular characterization of new group A streptococcal bacteriophages containing the gene for streptococcal erythrogenic toxin A (speA). Mol Gen Genet 231, 161-168.

Received 23 May 1997; revised 4 September 1997; accepted 12 November 1997. 